\title{
Surfactant protein D, Club cell protein 16, Pulmonary and activation-regulated chemokine, C-reactive protein, and Fibrinogen biomarker variation in chronic obstructive lung disease
}

\author{
Sofie Lock-Johansson ${ }^{1}$, Jørgen Vestbo ${ }^{2,3}$ and Grith Lykke Sorensen ${ }^{1 *}$
}

\begin{abstract}
Chronic obstructive pulmonary disease (COPD) is a multifaceted condition that cannot be fully described by the severity of airway obstruction. The limitations of spirometry and clinical history have prompted researchers to investigate a multitude of surrogate biomarkers of disease for the assessment of patients, prediction of risk, and guidance of treatment. The aim of this review is to provide a comprehensive summary of observations for a selection of recently investigated pulmonary inflammatory biomarkers (Surfactant protein D (SP-D), Club cell protein 16 (CC-16), and Pulmonary and activation-regulated chemokine (PARC/CCL-18)) and systemic inflammatory biomarkers (C-reactive protein (CRP) and fibrinogen) with COPD. The relevance of these biomarkers for COPD is discussed in terms of their biological plausibility, their independent association to disease and hard clinical outcomes, their modification by interventions, and whether changes in clinical outcomes are reflected by changes in the biomarker.
\end{abstract}

Keywords: COPD, Biomarker, SP-D, CC-16, PARC/CCL-18, CRP, Fibrinogen

\section{Introduction}

Chronic obstructive pulmonary disease (COPD) is a common disease worldwide [1] and is forecasted to be the 3rd leading cause of death globally in 2030 [2]. There is an unmet need for easily obtained biomarkers that can identify subtypes of COPD, predict outcomes of COPD, and that can evaluate and facilitate targeting in management of COPD. To aid in the evaluation and development of biomarkers for COPD, Sin \& Vestbo have formulated 5 criteria as an extension from the criteria for a biomarker proposed by Bucher et al. [3]. These criteria are: biological plausibility, independent association to disease, hard clinical outcomes, modification by interventions, and whether changes in clinical outcomes are reflected by changes in the biomarker [4]. The aim of this review is to summarize observations for a selection of investigated biomarkers for COPD, with guidance from these criteria. The selected biomarkers are recently validated

\footnotetext{
* Correspondence: glsorensen@health.sdu.dk

${ }^{1}$ Institute of Molecular Medicine, University of Southern Denmark, JB Winsloews Vej 25.3, Odense 5000, Denmark

Full list of author information is available at the end of the article
}

with regards to sensitivity, accuracy, precision and reproducibility [5]. Surfactant protein D (SP-D), club cell protein 16 (CC-16, previously named Clara cell protein), and pulmonary and activation-regulated chemokine (PARC/CCL-18) are categorized as pulmonary inflammatory markers, while C-reactive protein (CRP) and fibrinogen are systemic inflammatory markers.

\section{SP-D}

SP-D is a member of the collectin family [6] and is primarily produced in type II pneumocytes [7-9].

\section{Biological plausibility}

SP-D plays an essential role in pulmonary innate immune defense [10] and SP-D deficient mice exhibit abnormal accumulation of apoptotic macrophages. These animals also exhibit increased cytokine activation accompanied by lymphocyte infiltration and emphysema development [11-15], suggesting a protective role for SP-D in the pathogenesis of COPD. Several single nucleotide polymorphisms (SNPs) in the SP-D gene (Sftpd) have shown to associate with serum SP-D levels. 
In a twin-study, the coding SNP rs721917 was associated with lower SP-D levels in serum [16]. This finding was replicated in a cohort consisting of 1,719 COPD subjects in the "Evaluation of COPD Longitudinally to Identify Predictive Surrogate Endpoints" Study (ECLIPSE), where 28 SNPs were shown to influence serum SP-D. However, the strongest effect occurred with a promotor SNP (rs1885551), where the minor allele associated with lower serum SP-D [17]. In addition, three Sftpd SNPs (including rs721917) have been associated with forced expiratory volume $\left(\mathrm{FEV}_{1}\right) \%$ predicted [17], and five SNPs in Sftpd have been associated with an increased risk of COPD development in a Genome Wide Association study (GWAS) [18]. Lastly, a Japanese study reported one Sftpd SNP in association with emphysema [19].

\section{Independent association to disease}

SP-D has been measured in bronchoalveolar lavage fluid (BALF) and in blood. Among smokers, most studies have reported reduced levels of SP-D in BALF [20-23] and increased circulating levels [16,22,24,25]. Some studies have noted significant decreases in SP-D in BALF from COPD patients compared with current smokers [22] while others have not [20,21]. SP-D exists in different molecular forms (full-length, nitrosylated and cleaved). Yet, attempts to construct assays for the breakdown products of SP-D have not provided additional information regarding COPD [26].

Factors associated with increasing circulating SP-D in healthy subjects include age, BMI and male gender $[16,27,28]$. Circulating SP-D has been correlated with a variety of pulmonary pathologies [29], and a small comparative study showed that serum SP-D levels could not distinguish COPD from the other pulmonary pathologies [30].

A recent population-based study demonstrated a correlation between serum SP-D and reduced pulmonary function in tobacco smokers [31], suggesting that serum SP-D may serve as a marker for subclinical cigarette smoke induced lung damage. In concordance with this, in a relatively small COPD study, an inverse correlation between serum SP-D and $\mathrm{FEV}_{1} /$ forced vital capacity (FVC) ratio was found in smokers [22]. This result was however not replicated in the ECLIPSE multi-center cohort study [25,32], nor in a Swedish twin study [33], both of which contained non-smoker control subjects in addition to smoker control subjects.

In the ECLIPSE cohort, higher serum SP-D levels were reported among COPD patients relative to current and former smokers. COPD subjects who had serum SP-D concentrations in the upper 5th percentile of nonsmokers had (i) increased risk of exacerbations over the following 12 months [25], and (ii) increased serum SP-D concentrations during exacerbation of COPD compared with stable COPD [34,35]. Data from the ECLIPSE cohort have further demonstrated that baseline serum SP$\mathrm{D}$ levels were associated with a decline in lung density as measured by low-dosage high-resolution computed tomography [36].

\section{Hard clinical outcomes}

Further reports from the ECLIPSE cohort found that baseline serum SP-D levels were associated with 3-year all-cause mortality [37].

\section{Modification by interventions and correlations between changes in clinical outcomes and biomarker changes}

Three cohort studies have showed that treatment with oral corticosteroids resulted in suppressed serum SP-D levels $[25,38,39]$, whereof one showed that serum SP-D correlated with symptom relief and change in $\mathrm{FEV}_{1} \%$ predicted [38].

In summary, results from GWAS and animal studies suggest a strong link between SP-D levels and COPD. Smoking highly influences systemic SP-D levels and may be an explanation of the inconclusive findings of association between severity of COPD and systemic SP-D levels. SP-D has so far not proven to be a reliable prognostic tool in advanced COPD; however, stratification for tobacco smoking is warranted in such analyses and has been lacking. Although large studies have found associations between SP-D levels and early loss of pulmonary function as well as mortality and decline in lung density in COPD, these findings need to be further validated and the data representing intervention effects on SP-D are sparse.

\section{CC-16}

CC-16 is predominantly secreted from non-ciliated club cells [22] and is localized to both terminal bronchial epithelia [40] and respiratory bronchiolar epithelia [41,42]. An identical protein, human urinary protein 1 (P1), is secreted in the urogenital tract [43]. Systemic levels of CC-16 correlate well with BALF levels, and appear to be unaffected by the release of $\mathrm{P} 1$ from the urogenital tract in healthy subjects $[44,45]$. Circulating CC-16 levels reflect different chronic pulmonary pathologies, with circulating $\mathrm{CC}-16$ levels being positively associated with severity in sarcoidosis and asbestos-exposed workers [45-49]. However, circulating levels are negatively associated with the severity of asthma [50], cystic fibrosis (CF) [51] and lung cancer [45].

\section{Biological plausibility}

CC-16-deficient mice challenged with hyperoxia showed augmented pulmonary inflammation [52], and in vitro studies have indicated that CC-16 inhibits phospholipase 
$\mathrm{A}_{2}$ activity [53] suggesting an anti-inflammatory role of CC-16.

Candidate gene studies have reported an association between a SNP in the SCGB1A1 gene (Chromosome 11, A38G). Carriers exhibited reduced CC-16 plasma levels and an increased risk of asthma in a child cohort with European ancestry [54]; this association between asthma and SNP A38G was further replicated in adults [55]. However, in a Chinese population, no association between this SNP and COPD was found [56]. In a GWAS where serum CC-16 levels were measured in 1951 COPD subjects, associations between 11 SNPs on chromosome 11 (one of which was located in the SCGB1A1 gene) and serum CC-16 were found. These 11 SNPs were further evaluated in an additional 2,939 COPD cases and 1,380 smoking controls, and one SNP, located near the AHNAK gene, was associated with both COPD risk and frequency of exacerbation during a 2-year follow-up. However, in the same study, this finding could not be replicated in two additional control/COPD populations [18].

\section{Independent association to disease}

Confounding factors that increase systemic levels of CC16 in healthy subjects include age $[57,58]$, BMI (though with conflicting findings) $[33,59]$, and a decline in glomerular filtration rate [60].

Several studies have shown that circulating levels of CC-16 are lower in healthy smokers relative to nonsmokers, while other studies, examining the amount of smoking, have been inconclusive [50,61-63].

In the ECLIPSE study, CC-16 levels were reduced in former and current smokers with COPD relative to current smoking controls [63]. This finding was consistent with findings from previous smaller studies [33,45,64]. When stratifying COPD patients into GOLD groups and by current smoking, lower serum CC-16 levels were seen in current smoking COPD patients relative to former smokers in GOLD2 and GOLD3 but not in GOLD4. In former-smoking COPD patients, a significant inverse correlation was observed between CC-16 and COPD severity. Additionally, CC-16 could distinguish between patients with or without reversibility in former smoking COPD patients [63]. The evaluation of $\mathrm{FEV}_{1}$ decline over time in the ECLIPSE cohort showed a weak positive association between serum CC-16 and annual rate of decline in $\mathrm{FEV}_{1}$ [2]. This was recently validated in a cohort consisting of 4,724 COPD subjects, where reduced levels of $\mathrm{CC}-16$ were associated with accelerated decline in $\mathrm{FEV}_{1}$ over 9 years [65].

Repeated measurements of CC-16 in a sub-population from the ECLIPSE cohort found that serum CC-16 is a stable marker over time [66]. In a study including 357 twins with respiratory symptoms, a positive association with $\mathrm{FEV}_{1}$ and an inverse association with residual volume/total lung capacity were found. However, analysis of a sub-cohort of 100 COPD patients within this twin population found no significant association to these measures [33].

\section{Hard clinical outcomes}

Serum CC-16 did not associate independently with mortality in the ECLIPSE cohort [37].

\section{Modification by interventions and correlations between changes in clinical outcomes and biomarker changes} A pilot randomized clinical trial (RCT) with 16 cachectic COPD patients and 25 controls treated with TNF- $\alpha$ antibody reported a rise in plasma CC-16 in COPD patients after 8 weeks of treatment; treatment effects on other end-points were not considered in this study [67]. In an RCT with approximately 100 subjects in three treatment arms (a p38 mitogen-activated protein kinase (p38 MAPK) inhibitor, salmeterol/fluticasone propionate and placebo), a reduction in $\mathrm{CC}-16$ levels was seen in the salmeterol/fluticasone group after 2 weeks treatment [68].

In summary, results from animal studies suggest a causal role of CC-16 in COPD. However, the lack of a strong association between genotype variations, circulating CC-16 levels and risk of COPD indicates that CC-16 associates with pulmonary inflammation in general rather than with COPD pathogenesis explicitly. Furthermore, the inconsistent association to severity in COPD, the lack of association to mortality, the confounding effects in basal variation and the close association between CC-16 and asthma, all make the use of CC-16 as a biomarker in COPD problematic. However, additional studies validating the association between $\mathrm{CC}-16$ and $\mathrm{FEV}_{1}$ decline are warranted.

\section{PARC/CCL-18}

PARC/CCL-18 is a chemokine highly expressed in the lungs [69] with a chemotactic effect on primarily lymphocytes [70]. PARC/CCL-18 is synthesized mainly in dendritic and monocytic cells [71], but has also been shown to stimulate fibrinogenic activity and collagen production in lung fibroblasts [72,73]. Due to its predominant production in the lungs, PARC/CCL-18 has been evaluated in multiple pulmonary pathologies. In pulmonary fibrosis, an up-regulation in lung tissue [74] and an association to mortality has been reported [75].

\section{Biological plausibility}

No studies have directly addressed a mechanistic role for PARC/CCL-18 in COPD. 


\section{Independent association to disease}

LPS-inhalation challenge in smokers increased levels of PARC/CCL-18 in serum after 24 h [76]. Few studies have evaluated PARC/CCL-18 as a biomarker for COPD. One small study has shown an association between PARC/ CCL-18 and $\mathrm{FEV}_{1}$, Body Mass Index, Obstruction, Dyspnea score and Exercise capacity (BODE) index, and exacerbation rate [77]; another study reported elevated PARC/CCL-18 during COPD exacerbation [78]. The largest study to date of PARC/CCL-18 in COPD, included different COPD populations: 4,800 subjects from lung health study (LHS) with mild or moderate COPD, 1,800 COPD subjects from the ECLIPSE study representing all GOLD stages, 312 smoking and 226 non-smoking controls, and 89 COPD subjects from a prednisolone intervention study [79]. The results were somewhat contradictory. In LHS, higher PARC/CCL-18 levels associated with lower baseline $\mathrm{FEV}_{1}$ and increasing cardiovascular mortality. In the ECLIPSE subjects, PARC/ CCL-18 levels were higher in COPD subjects than in controls, but the association with $\mathrm{FEV}_{1}$ could not be replicated.

\section{Hard clinical outcomes}

PARC/CCL-18 was associated with all-cause mortality in the ECLIPSE cohort [79].

\section{Modification by interventions and correlations between changes in clinical outcomes and biomarker changes}

Two weeks treatment with prednisolone was associated with a significant reduction in PARC/CCL-18 levels compared to placebo in the ECLIPSE cohort [79].

In summary, although some evidence of association between PARC/CCL-18 and severity and mortality in COPD exists, additional validation and data regarding intervention effects on PARC/CCL-18 are warranted.

\section{CRP}

CRP is an acute phase protein, mainly induced by interleukin 6 (IL-6) and is a component of the innate immune response [80]. Increased systemic levels of CRP are seen in a variety of inflammatory conditions, particularly in infections.

\section{Biological plausibility}

The direct link between systemic inflammation and the development and progression of COPD is debated; however, the effect of CRP on activation of the complement system [80] can serve as a factor in maintaining an inflammatory state in stable COPD and thereby contribute to the negative systemic effects associated with COPD.
Although CRP levels are genetically determined [81], SNPs or haplotypes known to effect CRP levels have not been associated COPD risk [18,81-83].

\section{Independent association to disease}

In large population based case-control studies [84], as in large COPD cohorts [84-86] levels of CRP are demonstrably higher in stable COPD patients than in controls after adjusting for the confounding factors: sex, age, tobacco consumption and ischemic heart disease. Reported associations between CRP and airflow limitation have been inconsistent, with reports of weak to moderate unadjusted correlations between $\mathrm{FEV}_{1}$ and CRP [87-90]. Analysis of CRP association with COPD severity, after adjustment for age, gender, pack-year history, presence of cardiovascular risk factors or disease and treatment with inhaled corticosteroids, showed an inverse association with 6-minute walking distance (6MWD) [88,91], diffusing capacity (adjusted for age, gender, height, smoking and BMI) [33], and hypoxemia (adjusted for sex, age, body composition and smoking) [87]. However, in one additional study $(n=222)$ no association with 6MWD or BODE index was found [92].

A link between systemic inflammation and comorbidity in COPD has been suggested, and elevated CRP levels in COPD patients with cardiovascular disease (CVD) [93,94], type II diabetes [94], and lung cancer [94] have been reported. CRP furthermore associated with cardiovascular and cancer mortality [95]. In a recent study, higher levels of CRP were found in a "metabolic" comorbidity cluster with the characteristics of obesity, hyperglycemia, dyslipidemia, hypertension, and atherosclerosis when compared with the cluster of CVD without the metabolic features [96], indicating that the link between COPD, systemic inflammation and CVD could be metabolic impairment. CRP levels are higher during exacerbations than during stable COPD (AUC: 0.73) [78] and can be used to distinguish between exacerbation with or without bacterial infection (AUC: 0.8) [97,98]. In addition, CRP levels were higher in patients with frequent exacerbations compared to stable state patients [85], although CRP levels were not predictive of an exacerbation [99].

CRP has been shown to exhibit high variability over time. For example, in 201 COPD patients with CRP measured at baseline and 3 months later, only $21 \%$ had values within $25 \%$ of each other [66].

\section{Hard clinical outcomes}

CRP levels have been shown to predict all-cause mortality in a group with mild to moderate disease in a population-based cohort $(n=5000)$ [95], but not in a smaller $(n=218)$ cohort with moderate to severe COPD [90]. In the ECLIPSE cohort, higher CRP 
associated with all-cause mortality but did not alone contribute to better prediction of mortality than a multivariate model [88]. Another large COPD population study found that CRP levels predicted mortality and hospitalization [84].

\section{Modification by interventions and correlations between changes in clinical outcomes and biomarker changes} In a RCT with 41 COPD subjects, randomized to oral prednisolone, inhaled glucocorticoid or placebo, there was a significant fall in oral prednisolone and inhaled glucocorticoid compared to placebo [100].

In summary, evidence that CRP plays a causal role in COPD is controversial. There have been conflicting reports regarding the value of CRP to predict mortality and hospitalizations. Although associations with COPD have been reported, CRP may not be a suitable biomarker in COPD, due to its low specificity and high variability.

\section{Fibrinogen}

Fibrinogen is primarily synthesized in the liver [101], is involved in clotting formation [102] and systemic levels are elevated in an IL-6-stimulated acute phase response $[103,104]$.

\section{Biological plausibility}

The genes coding for three peptide chains in fibrinogen are located on chromosome 4 [105]. Circulating fibrinogen levels are genetically determined [106] and SNPs have been associated with risk of cardiovascular disease [106]. A candidate gene study with selected SNPs in the FBG gene encoding fibrinogen did not find an association with circulating fibrinogen levels [107]. A direct role in COPD is not found.

\section{Independent association to disease}

After adjusting for cardiovascular risk factors, several large population based cohorts have found an association between smoking and elevated systemic fibrinogen levels in healthy subjects [108-110]. A meta-analysis from "Fibrinogen Studies Collaboration" consisting of 154,211 apparently healthy subjects from 31 cohorts reported a positive association between fibrinogen and age, female gender, and alcohol abstinence [111].

Fibrinogen is shown to associate with the risk of COPD [112-114]. Higher fibrinogen levels were associated with the rate of decline in $\mathrm{FEV}_{1} / \mathrm{FVC}$ in a population of elderly subjects [115], and in cohorts with stable COPD patients, fibrinogen was shown to associate with $\mathrm{FEV}_{1}$ [2], dyspnea, exercise capacity [87] and the composite BODE index [116]. However, a study of 102 COPD patients did not report a significant association of fibrinogen with $\mathrm{FEV}_{1}$, but with diffusing capacity of the lung for carbon monoxide (DLCO) [117]. There have further been conflicting reports about the association between fibrinogen and decline in $\mathrm{FEV}_{1}$. In a COPD cohort, comprising 148 patients [118] an association between increasing fibrinogen levels and decline in $\mathrm{FEV}_{1}$ was found. However, this was not replicated in a small Japanese study $(n=73)$ [119], nor in the ECLIPSE investigation [2].

Fibrinogen has moreover been evaluated as a tool for distinguishing subgroups of COPD. In a small study of male COPD patients, a group with emphysematous lesions involving more than $15 \%$ of the lung parenchyma $(n=24)$ had higher fibrinogen levels than controls $(n=25)$ [120]. Elevated levels of fibrinogen in stable COPD patients have been shown to be predictive of risk of exacerbation [99,121,122], and elevated fibrinogen levels have been reported during an exacerbation [121]. Lastly, there has been a trend towards higher fibrinogen levels in patients suffering from exacerbations with accompanying purulent sputum [121], or virus infection [123].

Increased circulating fibrinogen levels have been suggested as a risk factor for cardiovascular disease and associated mortality [124]. In the meta-analysis from "Fibrinogen Studies Collaboration", a moderately strong association between fibrinogen and risk of coronary heart disease was reported [111]. However, a recent study from same group reported that cardiovascular event risk prediction when adding fibrinogen to a model with established risk factors gave little improvement [125]. In a Danish cohort of 8,656 COPD patients, fibrinogen alone was not a strong predictor for ischemic heart disease or myocardial infarction; however, together with CRP and leukocyte count, and hazard ratios for ischemic heart disease, myocardial infarction and heart failure were approximately two-fold higher in the group with high levels of the biomarkers compared to those with low-levels [94]. On the other hand, a small study of 60 COPD patients along with 20 smoking and 20 non-smoking controls showed no independent association between fibrinogen and flow-mediated vasodilatation (an independent predictor of cardiovascular morbidity and mortality) [38].

\section{Hard clinical outcomes}

Fibrinogen has been shown to associate with both the risk of COPD and of hospitalizations in a Swedish population cohort $(n=5,247)$ [112], in a Danish population cohort $(n=8,955)$, which also showed an inverse association to decline in $\mathrm{FEV}_{1}$ [113], and in a US population cohort $(n=20,192)$, that also found associations with GOLD group and mortality [114]. Fibrinogen has further been shown to predict all-cause mortality in COPD $[37,126]$, although in a later investigation, when comparing c-statistics, fibrinogen alone did not contribute to a better prediction of mortality 
than a basic model (including age, BODE index and hospitalizations).

\section{Modification by interventions and correlations between changes in clinical outcomes and biomarker changes} In a small study of patients with exacerbation $(\mathrm{n}=30)$, fibrinogen was suppressed by systemic corticosteroid treatment [127]. However, in a study of stable COPD, plasma fibrinogen was not affected by oral prednisolone [25]. In an RCT with approximately 100 subjects in three treatment arms (p38 mitogen-activated protein kinase (p38-MAPK) inhibitor, salmeterol/fluticasone propionate and placebo), treatment with a p38-MAPK inhibitor resulted in an 11\% reduction in plasma fibrinogen levels [68].

In summary, there has been no emerging evidence of direct causality between circulating fibrinogen levels and COPD. Fibrinogen levels have nevertheless been shown to be independently associated with COPD, prediction of allcause mortality, and risk of exacerbation. In addition, fibrinogen levels are modifiable by treatment interventions. As a systemic inflammatory marker with less variability over time than CRP, fibrinogen is an interesting candidate biomarker with putative value in distinguishing subtypes and comorbidity clusters in COPD and is currently being taken forward by the collaborative COPD Biomarker Qualification Consortium [128]. However, further investigations of fibrinogen in the assessment of treatment response are still needed.

\section{Summary and conclusion}

A summary of conclusions is provided in Table 1.

\section{Biological plausibility}

Findings from animal studies and gene-association studies point at a plausible role of the pulmonary proteins SP-D and CC-16 in COPD.

\section{Independent association to disease and hard clinical outcomes}

There is evidence that SP-D, CC-16 and PARC/CCL-18 reflect disease severity. Findings indicate association between pulmonary inflammatory proteins and risk of exacerbations, hospitalizations and death. However, results do not show the same consistency as with systemic inflammatory proteins. Fibrinogen appears to be a more specific biomarker for COPD than CRP, and is demonstrated to predict exacerbation risk and all-cause

Table 1 Summary of evidence of reviewed biomarkers in relation to questions raised by Sin \& Vestbo [4]

\begin{tabular}{|c|c|c|c|c|c|}
\hline & SP-D & CC-16 & $\begin{array}{l}\text { PARC/ } \\
\text { CCL-18 }\end{array}$ & CRP & Fibrinogen \\
\hline $\begin{array}{l}\text { Is there a strong biological } \\
\text { plausibility in terms of its role } \\
\text { in pathogenesis of disease? }\end{array}$ & $\begin{array}{l}\text { Evidence from } \\
\text { animal studies and } \\
\text { gene-association } \\
\text { studies [10-19] }\end{array}$ & $\begin{array}{l}\text { Suggested from in } \\
\text { vitro, animal study and } \\
\text { gene-association studies } \\
{[18,52,53]}\end{array}$ & N.A. & $\begin{array}{l}\text { Experimental data } \\
\text { suggest role in } \\
\text { systemic effects and } \\
\text { comorbidity [81] }\end{array}$ & $\begin{array}{l}\text { Experimental data } \\
\text { suggest role in } \\
\text { systemic effects and } \\
\text { comorbidity }[108,109]\end{array}$ \\
\hline $\begin{array}{l}\text { Is there a strong, consistent and } \\
\text { independent association between } \\
\text { the biomarker and COPD? }\end{array}$ & Level IIb[16,20-35] & Level IIb [33,45,63-66] & $\begin{array}{l}\text { Level III } \\
{[77-79]}\end{array}$ & $\begin{array}{l}\text { Conflicting results } \\
\text { from large } \\
\text { population studies } \\
{[78,85-99]}\end{array}$ & $\begin{array}{l}\text { Level Ilb } \\
{[32,87,112-122,125]}\end{array}$ \\
\hline $\begin{array}{l}\text { Is there a strong, independent } \\
\text { association between the }\end{array}$ & Level Ila $[36,37]$ & No evidence [37] & Level IIb [79] & $\begin{array}{l}\text { Level Ila; on all cause } \\
\text { mortality }[84,86,99]\end{array}$ & $\begin{array}{l}\text { Level Ila } \\
{[37,112-114,126]}\end{array}$ \\
\hline
\end{tabular}

biomarker and hard clinical

outcomes such as mortality and

hospitalisations?

Is there evidence from randomised controlled trials that the biomarker is modifiable by interventions?

\section{Evidence from 3 cohort studies of prednisolone} treatment $[25,38,39]$

Evidence from one RCT
of TNF-R antibody
treatment [67] and one
RCT in salmeterol/
fluticasone propionate-
arm [68]

N.A.
Evidence from one RCT with prednisolone treatment [79]

N.A.
Evidence from one $\mathrm{RCT}$ with inhaled glucocorticoid prednisolone or placebo [100]

N.A.
Evidence from one RCT with p38 MAPK inhibitor[68,127]

$\mathrm{FEV}_{1}$ and health status)?

la - Evidence from Meta-analysis of Randomized Controlled Trial, lb - Evidence from at least one Randomized Controlled Trial, lla - Evidence from at least one well designed controlled trial which is not randomized, Ilb - Evidence from at least one well designed experimental trial, III - Evidence from case, correlation, and comparative studies, IV - Evidence from a panel of experts. SP-D: Surfactant protein D, CC-16: club cell protein 16, PARC/CCL-18: pulmonary and activation-regulated chemokine 18, CRP: C-reactive protein. N.A.: no available studies. 
mortality. However, systemic inflammatory proteins are influenced by additional pathologies such as heart disease and metabolic disturbances, which are both common comorbidities in COPD. As the only one of the above reviewed biomarkers $\mathrm{CC}-16$ has showed to associate with decline in lung function, which indicates a utility in evaluation of disease activity.

\section{Modification by interventions and correlations between changes in clinical outcomes and biomarker changes} All of the reviewed biomarkers have showed to be modifiable by either oral prednisolone or inhaled glucocorticoid to different extents. However, only few randomized clinical trials have been evaluating this matter. Though biomarkers in COPD are extensively investigated, most of the studies comprise cohort and experimental studies. Randomized clinical trials evaluating changes in biomarkers in relation to interventions and clinical outcome are lacking.

In conclusion, none of the biomarkers in this review fulfill all of the criteria presented by Sin \& Vestbo [4] and an additive approach, with different biomarkers combined, may contribute to increased specificity and sensitivity for prognosis of COPD.

\section{Competing interests}

Sofie Lock Johansson and Grith Lykke Sorensen have no declared competing interests. Jørgen Vestbo has not received any financial support in relation to the current manuscript. Outside this work he has received honoraria for advising and presenting from AstraZeneca, Boehringer-Ingelheim, Chiesi, GSK, and Novartis. He co-chaired the ECLIPSE study, funded by GSK.

\section{Authors' contributions}

$S L$, JV and GLS have made substantial contributions to conception and design. SLJ have drafted the manuscript. JV and GLS have revised the manuscript critically. All authors have given final approval of the version to be published. All authors agree to be accountable for all aspects of the work.

\section{Acknowledgements}

Funding was obtained from the Region of Southern Denmark, Odense University Hospital Research Council, the Danish Strategic Research Council, Centre of COPD research (www.cekol.dk) (09-066945), the Danish Lung Association.

\section{Author details \\ ${ }^{1}$ Institute of Molecular Medicine, University of Southern Denmark, JB Winsloews Vej 25.3, Odense 5000, Denmark. ${ }^{2}$ Department of Respiratory Medicine, Gentofte Hospital, Hellerup, Denmark. ${ }^{3}$ Respiratory Research Group, Manchester Academic Science Centre University Hospital South Manchester NHS Foundation Trust Manchester, Manchester, UK.}

Received: 24 August 2014 Accepted: 7 November 2014

Published online: 25 November 2014

\section{References}

1. Lozano R, Naghavi M, Foreman K, Lim S, Shibuya K, Aboyans V, Abraham J, Adair T, Aggarwal R, Ahn SY, Alvarado M, Anderson HR, Anderson LM, Andrews KG, Atkinson C, Baddour LM, Barker-Collo S, Bartels DH, Bell ML, Benjamin EJ, Bennett D, Bhalla K, Bikbov B, Bin Abdulhak A, Birbeck G, Blyth F, Bolliger I, Boufous S, Bucello C, Burch M: Global and regional mortality from 235 causes of death for 20 age groups in 1990 and 2010: a systematic analysis for the Global Burden of Disease Study 2010. Lancet 2012, 380:2095-2128.
2. Chronic obstructive pulmonary disease (COPD) http://www.who.int/ respiratory/copd/en/

3. Bucher HC, Guyatt GH, Cook DJ, Holbrook A, McAlister FA: Users' guides to the medical literature: XIX. Applying clinical trial results. A. How to use an article measuring the effect of an intervention on surrogate end points. Evidence-Based Medicine Working Group. JAMA 1999, 282:771-778.

4. Sin DD, Vestbo J: Biomarkers in chronic obstructive pulmonary disease. Proc Am Thorac Soc 2009, 6:543-545.

5. Christensen AF, Hoegh SV, Lottenburger T, Holmskov U, Tornoe I, HorslevPetersen K, Sorensen GL, Junker P: Circadian rhythm and the influence of physical activity on circulating surfactant protein D in early and longstanding rheumatoid arthritis. Rheumatol Int 2011, 31:1617-1623.

6. Day AJ: The C-type carbohydrate recognition domain (CRD) superfamily. Biochem Soc Trans 1994, 22:83-88.

7. Persson A, Rust K, Chang D, Moxley M, Longmore W, Crouch E: CP4: a pneumocyte-derived collagenous surfactant-associated protein. Evidence for heterogeneity of collagenous surfactant proteins. Biochemistry 1988, 27:8576-8584.

8. Voorhout WF, Veenendaal T, Kuroki Y, Ogasawara Y, van Golde LM, Geuze HJ: Immunocytochemical localization of surfactant protein D (SP-D) in type II cells, Clara cells, and alveolar macrophages of rat lung. J Histochem Cytochem 1992, 40:1589-1597.

9. Madsen J, Kliem A, Tornoe I, Skjodt K, Koch C, Holmskov U: Localization of lung surfactant protein $D$ on mucosal surfaces in human tissues. J Immunol 2000, 164:5866-5870.

10. Crouch E, Wright JR: Surfactant proteins a and $d$ and pulmonary host defense. Annu Rev Physiol 2001, 63:521-554.

11. Wert SE, Yoshida M, LeVine AM, Ikegami M, Jones T, Ross GF, Fisher JH, Korfhagen TR, Whitsett JA: Increased metalloproteinase activity, oxidant production, and emphysema in surfactant protein $D$ gene-inactivated mice. Proc Natl Acad Sci U S A 2000, 97:5972-5977.

12. Fisher JH, Larson J, Cool C, Dow SW: Lymphocyte activation in the lungs of SP-D null mice. Am J Respir Cell Mol Biol 2002, 27:24-33.

13. Botas C, Poulain F, Akiyama J, Brown C, Allen L, Goerke J, Clements J, Carlson E, Gillespie AM, Epstein C, Hawgood S: Altered surfactant homeostasis and alveolar type II cell morphology in mice lacking surfactant protein D. Proc Natl Acad Sci U S A 1998, 95:11869-11874.

14. Yoshida M, Whitsett JA: Alveolar macrophages and emphysema in surfactant protein-D-deficient mice. Respirology 2006, 11(Suppl):S37-S40.

15. Collins RA, Ikegami M, Korfhagen TR, Whitsett JA, Sly PD: In vivo measurements of changes in respiratory mechanics with age in mice deficient in surfactant protein D. Pediatr Res 2003, 53:463-467.

16. Sorensen GL, Hjelmborg J, Kyvik KO, Fenger M, Hoj A, Bendixen C, Sorensen TI, Holmskov U: Genetic and environmental influences of surfactant protein D serum levels. Am J Physiol Lung Cell Mol Physiol 2006, 290:L1010-L1017.

17. Foreman MG, Kong X, DeMeo DL, Pillai SG, Hersh CP, Bakke P, Gulsvik A, Lomas DA, Litonjua AA, Shapiro SD, Tal-Singer R, Silverman EK: Polymorphisms in surfactant protein-D are associated with chronic obstructive pulmonary disease. Am J Respir Cell Mol Biol 2011, 44:316-322.

18. Kim DK, Cho MH, Hersh CP, Lomas DA, Miller BE, Kong X, Bakke P, Gulsvik A, Agusti A, Wouters E, Celli B, Coxson H, Vestbo J, MacNee W, Yates JC, Rennard S, Litonjua A, Qiu W, Beaty TH, Crapo JD, Riley JH, Tal-Singer R, Silverman EK, ECLIPSE, ICGN, and COPDGene Investigators: Genome-wide association analysis of blood biomarkers in chronic obstructive pulmonary disease. Am J Respir Crit Care Med 2012, 186:1238-1247.

19. Ishii T, Hagiwara K, Kamio K, Ikeda S, Arai T, Mieno MN, Kumasaka T, Muramatsu M, Sawabe M, Gemma A, Kida K: Involvement of surfactant protein $D$ in emphysema revealed by genetic association study. Eur $J$ Hum Genet 2012, 20:230-235.

20. More JM, Voelker DR, Silveira LJ, Edwards MG, Chan ED, Bowler RP: Smoking reduces surfactant protein $D$ and phospholipids in patients with and without chronic obstructive pulmonary disease. BMC Pulm Med 2010, 10:53.

21. Betsuyaku T, Kuroki Y, Nagai K, Nasuhara Y, Nishimura M: Effects of ageing and smoking on SP-A and SP-D levels in bronchoalveolar lavage fluid. Eur Respir J 2004, 24:964-970.

22. Winkler C, Atochina-Vasserman EN, Holz O, Beers MF, Erpenbeck VJ, Krug N, Roepcke S, Lauer G, Elmlinger M, Hohlfeld JM: Comprehensive characterisation of pulmonary and serum surfactant protein D in COPD. Respir Res 2011, 12:29. 
23. Honda Y, Takahashi H, Kuroki Y, Akino T, Abe S: Decreased contents of surfactant proteins A and D in BAL fluids of healthy smokers. Chest 1996, 109:1006-1009.

24. Mutti A, Corradi M, Goldoni M, Vettori MV, Bernard A, Apostoli P: Exhaled metallic elements and serum pneumoproteins in asymptomatic smokers and patients with COPD or asthma. Chest 2006, 129:1288-1297.

25. Lomas DA, Silverman EK, Edwards LD, Locantore NW, Miller BE, Horstman $\mathrm{DH}$, Tal-Singer R: Serum surfactant protein $\mathrm{D}$ is steroid sensitive and associated with exacerbations of COPD. Eur Respir J 2009, 34:95-102.

26. Duvoix A, Miranda E, Perez J, Sorensen GL, Holmskov U, Trapnell BC, Madsen J, Clark HW, Edwards LD, Miller BE, Tal-Singer RM, Lomas DA Evaluation of full-length, cleaved and nitrosylated serum surfactant protein D as biomarkers for COPD. COPD 2011, 8:79-95.

27. Sorensen GL, Hjelmborg JV, Leth-Larsen R, Schmidt V, Fenger M, Poulain F, Hawgood S, Sorensen TI, Kyvik KO, Holmskov U: Surfactant protein D of the innate immune defence is inversely associated with human obesity and SP-D deficiency infers increased body weight in mice. Scand J Immunol 2006, 64:633-638.

28. Zhao XM, Wu YP, Wei R, Cai HX, Tornoe I, Han JJ, Wang Y, de Groot PG, Holmskov U, Xia ZL, Sorensen GL: Plasma surfactant protein D levels and the relation to body mass index in a chinese population. Scand J Immunol 2007, 66:71-76.

29. Sorensen GL, Husby S, Holmskov U: Surfactant protein A and surfactant protein D variation in pulmonary disease. Immunobiology 2007, 212:381-416.

30. Kobayashi $H$, Kanoh S, Motoyoshi K: Serum surfactant protein-A, but not surfactant protein-D or KL-6, can predict preclinical lung damage induced by smoking. Biomarkers 2008, 13:385-392.

31. Colin Mathers TBaDMF: The Global Burden of Disease: 2004 Update, 2008. WHO Press: WHO Library Cataloguing-in-Publication Data: World Health Organization; 2008.

32. Vestbo J, Edwards LD, Scanlon PD, Yates JC, Agusti A, Bakke P, Calverley PM, Celli B, Coxson HO, Crim C, Lomas DA, MacNee W, Miller BE, Silverman EK, Tal-Singer R, Wouters E, Rennard SI, ECLIPSE Investigators: Changes in forced expiratory volume in 1 second over time in COPD. $N$ Engl J Med 2011, 365:1184-1192.

33. Engstrom G, Lindberg C, Gerhardsson De Verdier M, Nihlen U, Anderson M, Svartengren M, Forsman Semb K: Blood biomarkers and measures of pulmonary function-a study from the Swedish twin registry. Respir Med 2012, 106:1250-1257.

34. Ju CR, Liu W, Chen RC: Serum surfactant protein D: biomarker of chronic obstructive pulmonary disease. Dis Markers 2012, 32:281-287.

35. Shakoori TA, Sin DD, Ghafoor F, Bashir S, Bokhari SN: Serum surfactant protein $D$ during acute exacerbations of chronic obstructive pulmonary disease. Dis Markers 2009, 27:287-294.

36. Coxson HO, Dirksen A, Edwards LD, Yates JC, Agusti A, Bakke P, Calverley PM, Celli B, Crim C, Duvoix A, Fauerbach PN, Lomas DA, Macnee W, Mayer RJ, Miller BE, Müller NL, Rennard SI, Silverman EK, Tal-Singer R, Wouters EF, Vestbo J, Evaluation of COPD Longitudinally to Identify Predictive Surrogate Endpoints (ECLIPSE) Investigators: The presence and progression of emphysema in COPD as determined by CT scanning and biomarker expression: a prospective analysis from the ECLIPSE study. Lancet Respir Med 2013, 1:129-136

37. Celli BR, Locantore N, Yates J, Tal-Singer R, Miller BE, Bakke P, Calverley P, Coxson H, Crim C, Edwards LD, Lomas DA, Duvoix A, MacNee W, Rennard S, Silverman E, Vestbo J, Wouters E, Agustí A, ECLIPSE Investigators: Inflammatory biomarkers improve clinical prediction of mortality in chronic obstructive pulmonary disease. Am J Respir Crit Care Med 2012, 185:1065-1072.

38. Eickhoff P, Valipour A, Kiss D, Schreder M, Cekici L, Geyer K, Kohansal R, Burghuber OC: Determinants of systemic vascular function in patients with stable chronic obstructive pulmonary disease. Am J Respir Crit Care Med 2008, 178:1211-1218.

39. Liu W, Ju CR, Chen RC, Liu ZG: Role of serum and induced sputum surfactant protein $\mathrm{D}$ in predicting the response to treatment in chronic obstructive pulmonary disease. Exp Ther Med 2014, 8:1313-1317.

40. Singh G, Singh J, Katyal SL, Brown WE, Kramps JA, Paradis IL, Dauber JH, Macpherson TA, Squeglia N: Identification, cellular localization, isolation, and characterization of human Clara cell-specific $10 \mathrm{KD}$ protein. J Histochem Cytochem 1988, 36:73-80.

41. Broers $J$, Jensen $S M$, Travis WD, Pass H, Whitsett JA, Singh G, Katyal SL, Gazdar AF, Minna JD, Linnoila RI: Expression of surfactant associated
protein-A and Clara cell 10 kilodalton mRNA in neoplastic and non-neoplastic human lung tissue as detected by in situ hybridization. Lab Invest 1992, 66:337-346

42. Boers JE, Ambergen AW, Thunnissen FB: Number and proliferation of clara cells in normal human airway epithelium. Am J Respir Crit Care Med 1999, 159:1585-1591.

43. Bernard A, Roels H, Lauwerys R, Witters R, Gielens C, Soumillion A, Van Damme J, De Ley M: Human urinary protein 1: evidence for identity with the Clara cell protein and occurrence in respiratory tract and urogenital secretions. Clin Chim Acta 1992, 207:239-249.

44. Shijubo N, Itoh Y, Yamaguchi T, Shibuya Y, Morita Y, Hirasawa M, Okutani R, Kawai T, Abe S: Serum and BAL Clara cell 10 kDa protein (CC10) levels and CC10-positive bronchiolar cells are decreased in smokers. Eur Respir J 1997, 10:1108-1114.

45. Bernard A, Marchandise FX, Depelchin S, Lauwerys R, Sibille Y: Clara cell protein in serum and bronchoalveolar lavage. Eur Respir J 1992, 5:1231-1238.

46. Shijubo N, Itoh Y, Shigehara K, Yamaguchi T, Itoh K, Shibuya Y, Takahashi R, Ohchi T, Ohmichi M, Hiraga Y, Abe S: Association of Clara cell 10-kDa protein, spontaneous regression and sarcoidosis. Eur Respir J 2000, 16:414-419.

47. Hermans C, Petrek M, Kolek V, Weynand B, Pieters T, Lambert M, Bernard A: Serum Clara cell protein (CC16), a marker of the integrity of the airblood barrier in sarcoidosis. Eur Respir J 2001, 18:507-514.

48. Janssen R, Sato H, Grutters JC, Bernard A, van Velzen-Blad H, du Bois RM, van den Bosch JM: Study of Clara cell 16, KL-6, and surfactant protein-D in serum as disease markers in pulmonary sarcoidosis. Chest 2003, 124:2119-2125.

49. Lesur O, Bernard AM, Begin RO: Clara cell protein (CC-16) and surfactantassociated protein A (SP-A) in asbestos-exposed workers. Chest 1996, 109:467-474.

50. Shijubo N, Itoh Y, Yamaguchi T, Sugaya F, Hirasawa M, Yamada T, Kawai T, Abe S: Serum levels of Clara cell 10-kDa protein are decreased in patients with asthma. Lung 1999, 177:45-52.

51. Starosta V, Ratjen F, Rietschel E, Paul K, Griese M: Anti-inflammatory cytokines in cystic fibrosis lung disease. Eur Respir J 2006, 28:581-587.

52. Johnston CJ, Mango GW, Finkelstein JN, Stripp BR: Altered pulmonary response to hyperoxia in Clara cell secretory protein deficient mice. Am J Respir Cell Mol Biol 1997, 17:147-155.

53. Lesur O, Bernard A, Arsalane K, Lauwerys R, Begin R, Cantin A, Lane D: Clara cell protein (CC-16) induces a phospholipase A2-mediated inhibition of fibroblast migration in vitro. Am J Respir Crit Care Med 1995, 152:290-297.

54. Laing IA, Hermans C, Bernard A, Burton PR, Goldblatt J, Le Souef PN: Association between plasma CC16 levels, the A38G polymorphism, and asthma. Am J Respir Crit Care Med 2000, 161:124-127.

55. Candelaria PV, Backer V, Laing IA, Porsbjerg C, Nepper-Christensen S, de Klerk N, Goldblatt J, Le Souef PN: Association between asthma-related phenotypes and the CC16 A38G polymorphism in an unselected population of young adult Danes. Immunogenetics 2005, 57:25-32.

56. Liu S, Li B, Zhou Y, Zhong N, Ran P: Genetic analysis of CC16, OGG1 and GCLC polymorphisms and susceptibility to COPD. Respirology 2007, 12:29-33.

57. Nomori H, Horio H, Fuyuno G, Kobayashi R, Morinaga S, Hirabayashi Y: Protein 1 (Clara cell protein) serum levels in healthy subjects and patients with bacterial pneumonia. Am J Respir Crit Care Med 1995, 152:746-750.

58. Bernard AM, Roels HA, Buchet JP, Lauwerys RR: Serum Clara cell protein: an indicator of bronchial cell dysfunction caused by tobacco smoking. Environ Res 1994, 66:96-104.

59. Nomori H, Horio H, Takagi M, Kobayashi R, Hirabayashi Y: Clara cell protein correlation with hyperlipidemia. Chest 1996, 110:680-684.

60. Hermans C, Dong P, Robin M, Jadoul M, Bernard A, Bersten AD, Doyle IR: Determinants of serum levels of surfactant proteins $A$ and $B$ and Clara cell protein CC16. Biomarkers 2003, 8:461-471.

61. Ekberg-Jansson A, Andersson B, Bake B, Boijsen M, Enanden I, Rosengren A, Skoogh BE, Tylen U, Venge P, Lofdahl CG: Neutrophil-associated activation markers in healthy smokers relates to a fall in $\mathrm{DL}(\mathrm{CO})$ and to emphysematous changes on high resolution CT. Respir Med 2001, 95:363-373.

62. Van Miert E, Sardella A, Bernard A: Biomarkers of early respiratory effects in smoking adolescents. Eur Respir J 2011, 38:1287-1293.

63. Lomas DA, Silverman EK, Edwards LD, Miller BE, Coxson HO, Tal-Singer R: Evaluation of serum CC-16 as a biomarker for COPD in the ECLIPSE cohort. Thorax 2008, 63:1058-1063. 
64. Sin DD, Leung R, Gan WQ, Man SP: Circulating surfactant protein D as a potential lung-specific biomarker of health outcomes in COPD: a pilot study. BMC Pulm Med 2007, 7:13

65. Park HY, Churg A, Wright JL, Li Y, Tam S, Man SP, Tashkin D, Wise RA, Connett JE, Sin DD: Club Cell Protein 16 and Disease Progression in Chronic Obstructive Pulmonary Disease (COPD). Am J Respir Crit Care Med 2013, 188:1413-1419.

66. Dickens JA, Miller BE, Edwards LD, Silverman EK, Lomas DA, Tal-Singer R: COPD association and repeatability of blood biomarkers in the ECLIPSE cohort. Respir Res 2011, 12:146.

67. Dentener MA, Creutzberg EC, Pennings HJ, Rijkers GT, Mercken E, Wouters EF: Effect of infliximab on local and systemic inflammation in chronic obstructive pulmonary disease: a pilot study. Respiration 2008, 76:275-282.

68. Lomas DA, Lipson DA, Miller BE, Willits L, Keene O, Barnacle H, Barnes NC, Tal-Singer R: An oral inhibitor of p38 MAP kinase reduces plasma fibrinogen in patients with chronic obstructive pulmonary disease. J Clin Pharmacol 2012, 52:416-424.

69. Hieshima K, Imai T, Baba M, Shoudai K, Ishizuka K, Nakagawa T, Tsuruta J, Takeya M, Sakaki Y, Takatsuki K, Miura R, Opdenakker G, Van Damme J, Yoshie O, Nomiyama H: A novel human CC chemokine PARC that is most homologous to macrophage-inflammatory protein-1 alpha/LD78 alpha and chemotactic for T lymphocytes, but not for monocytes. J Immunol 1997, 159:1140-1149.

70. Adema GJ, Hartgers F, Verstraten R, de Vries E, Marland G, Menon S, Foster J, Xu Y, Nooyen P, McClanahan T, Bacon KB, Figdor CG: A dendritic-cellderived C-C chemokine that preferentially attracts naive T cells. Nature 1997, 387:713-717

71. Schraufstatter I, Takamori H, Sikora L, Sriramarao P, DiScipio RG: Eosinophils and monocytes produce pulmonary and activation-regulated chemokine, which activates cultured monocytes/macrophages. Am J Physiol Lung Cell Mol Physiol 2004, 286:L494-L501.

72. Atamas SP, Luzina IG, Choi J, Tsymbalyuk N, Carbonetti NH, Singh IS, Trojanowska M, Jimenez SA, White B: Pulmonary and activation-regulated chemokine stimulates collagen production in lung fibroblasts. Am Respir Cell Mol Biol 2003, 29:743-749.

73. Song E, Ouyang N, Horbelt M, Antus B, Wang M, Exton MS: Influence of alternatively and classically activated macrophages on fibrogenic activities of human fibroblasts. Cell Immunol 2000, 204:19-28.

74. Pardo A, Smith KM, Abrams J, Coffman R, Bustos M, McClanahan TK, Grein J, Murphy EE, Zlotnik A, Selman M: CCL18/DC-CK-1/PARC up-regulation in hypersensitivity pneumonitis. J Leukoc Biol 2001, 70:610-616.

75. Prasse A, Probst C, Bargagli E, Zissel G, Toews GB, Flaherty KR, Olschewski M, Rottoli P, Muller-Quernheim J: Serum CC-chemokine ligand 18 concentration predicts outcome in idiopathic pulmonary fibrosis. Am J Respir Crit Care Med 2009, 179:717-723.

76. Aul R, Armstrong J, Duvoix A, Lomas D, Hayes B, Miller BE, Jagger C, Singh D: Inhaled LPS challenges in smokers: a study of pulmonary and systemic effects. Br J Clin Pharmacol 2012, 74:1023-1032.

77. Pinto-Plata V, Toso J, Lee K, Park D, Bilello J, Mullerova H, De Souza MM, Vessey R, Celli B: Profiling serum biomarkers in patients with COPD: associations with clinical parameters. Thorax 2007, 62:595-601.

78. Hurst JR, Donaldson GC, Perera WR, Wilkinson TM, Bilello JA, Hagan GW, Vessey RS, Wedzicha JA: Use of plasma biomarkers at exacerbation of chronic obstructive pulmonary disease. Am J Respir Crit Care Med 2006 174:867-874.

79. Sin DD, Miller BE, Duvoix A, Man SF, Zhang X, Silverman EK, Connett JE, Anthonisen NA, Wise RA, Tashkin D, Celli BR, Edwards LD, Locantore N, Macnee W, Tal-Singer R, Lomas DA, ECLIPSE Investigators: Serum PARC/ CCL-18 concentrations and health outcomes in chronic obstructive pulmonary disease. Am J Respir Crit Care Med 2011, 183:1187-1192.

80. Volanakis JE: Human C-reactive protein: expression, structure, and function. Mol Immunol 2001, 38:189-197.

81. Hersh CP, Miller DT, Kwiatkowski DJ, Silverman EK: Genetic determinants of C-reactive protein in COPD. Eur Respir J 2006, 28:1156-1162.

82. Dahl M, Vestbo J, Zacho J, Lange P, Tybjaerg-Hansen A, Nordestgaard BG: C reactive protein and chronic obstructive pulmonary disease: a Mendelian randomisation approach. Thorax 2011, 66:197-204.

83. van Durme YM, Verhamme KM, Aarnoudse AJ, Van Pottelberge GR, Hofman A, Witteman JC, Joos GF, Brusselle GG, Stricker BH: C-reactive protein levels, haplotypes, and the risk of incident chronic obstructive pulmonary disease. Am J Respir Crit Care Med 2009, 179:375-382.
84. Dahl M, Vestbo J, Lange P, Bojesen SE, Tybjaerg-Hansen A, Nordestgaard BG: C-reactive protein as a predictor of prognosis in chronic obstructive pulmonary disease. Am J Respir Crit Care Med 2007, 175:250-255.

85. Eagan TM, Ueland T, Wagner PD, Hardie JA, Mollnes TE, Damas JK, Aukrust $P$, Bakke PS: Systemic inflammatory markers in COPD: results from the Bergen COPD Cohort Study. Eur Respir J 2010, 35:540-548.

86. Agusti A, Edwards LD, Rennard SI, MacNee W, Tal-Singer R, Miller BE, Vestbo J, Lomas DA, Calverley PM, Wouters E, Crim C, Yates JC, Silverman EK, Coxson HO, Bakke P, Mayer RJ, Celli B, valuation of COPD Longitudinally to Identify Predictive Surrogate Endpoints (ECLIPSE) Investigators: Persistent systemic inflammation is associated with poor clinical outcomes in COPD: a novel phenotype. PLoS One 2012, 7:e37483.

87. Garcia-Rio F, Miravitlles M, Soriano JB, Munoz L, Duran-Tauleria E, Sanchez G, Sobradillo V, Ancochea J: Systemic inflammation in chronic obstructive pulmonary disease: a population-based study. Respir Res 2010, 11:63

88. de Torres JP, Pinto-Plata V, Casanova C, Mullerova H, Cordoba-Lanus E, Muros De Fuentes M, Aguirre Jaime A, Celli BR: C-reactive protein levels and survival in patients with moderate to very severe COPD. Chest 2008 , 133:1336-1343.

89. Broekhuizen R, Wouters EF, Creutzberg EC, Schols AM: Raised CRP levels mark metabolic and functional impairment in advanced COPD. Thorax 2006, 61:17-22.

90. Thorleifsson SJ, Margretardottir OB, Gudmundsson G, Olafsson I, Benediktsdottir B, Janson C, Buist AS, Gislason T: Chronic airflow obstruction and markers of systemic inflammation: results from the BOLD study in Iceland. Respir Med 2009, 103:1548-1553.

91. Pinto-Plata VM, Mullerova H, Toso JF, Feudjo-Tepie M, Soriano JB, Vessey RS, Celli BR: C-reactive protein in patients with COPD, control smokers and non-smokers. Thorax 2006, 61:23-28.

92. Gaki E, Kontogianni K, Papaioannou Al, Bakakos P, Gourgoulianis KI, Kostikas K, Alchanatis M, Papiris S, Loukides S: Associations between BODE index and systemic inflammatory biomarkers in COPD. COPD 2011, 8:408-413.

93. Sin DD, Man SF: Why are patients with chronic obstructive pulmonary disease at increased risk of cardiovascular diseases? The potential role of systemic inflammation in chronic obstructive pulmonary disease. Circulation 2003, 107:1514-1519.

94. Thomsen M, Dahl M, Lange P, Vestbo J, Nordestgaard BG: Inflammatory biomarkers and comorbidities in chronic obstructive pulmonary disease. Am J Respir Crit Care Med 2012, 186:982-988.

95. Man SF, Connett JE, Anthonisen NR, Wise RA, Tashkin DP, Sin DD: Creactive protein and mortality in mild to moderate chronic obstructive pulmonary disease. Thorax 2006, 61:849-853.

96. Vanfleteren LE, Spruit MA, Groenen M, Gaffron S, Van Empel VP, Bruijnzeel PL, Rutten EP, Op T, Roodt J, Wouters EF, Franssen FM: Clusters of Comorbidities Based on Validated Objective Measurements and Systemic Inflammation in Patients with Chronic Obstructive Pulmonary disease. Am J Respir Crit Care Med 2013, 187:728-735.

97. Peng C, Tian C, Zhang Y, Yang X, Feng Y, Fan H: C-reactive protein levels predict bacterial exacerbation in patients with chronic obstructive pulmonary disease. Am J Med Sci 2013, 345:190-194.

98. Weis N, Almdal T: C-reactive protein-can it be used as a marker of infection in patients with exacerbation of chronic obstructive pulmonary disease? Eur J Intern Med 2006, 17:88-91.

99. Groenewegen KH, Postma DS, Hop WC, Wielders PL, Schlosser NJ, Wouters EF: Increased systemic inflammation is a risk factor for COPD exacerbations. Chest 2008, 133:350-357.

100. Sin DD, Lacy P, York E, Man SF: Effects of fluticasone on systemic markers of inflammation in chronic obstructive pulmonary disease. Am J Respir Crit Care Med 2004, 170:760-765.

101. Takeda Y: Studies of the metabolism and distribution of fibrinogen in healthy men with autologous 125-I-labeled fibrinogen. J Clin Invest 1966, 45:103-111.

102. Standeven KF, Ariens RA, Grant PJ: The molecular physiology and pathology of fibrin structure/function. Blood Rev 2005, 19:275-288.

103. Gabay C, Kushner I: Acute-phase proteins and other systemic responses to inflammation. N Engl J Med 1999, 340:448-454.

104. Huber $P$, Laurent M, Dalmon J: Human beta-fibrinogen gene expression. Upstream sequences involved in its tissue specific expression and its dexamethasone and interleukin 6 stimulation. J Biol Chem 1990, 265:5695-5701. 
105. Fish RJ, Neerman-Arbez M: Fibrinogen gene regulation. Thromb Haemost 2012, 108:419-426.

106. Yang Q, Tofler GH, Cupples LA, Larson MG, Feng D, Lindpaintner K, Levy D, D'Agostino RB, O'Donnell CJ: A genome-wide search for genes affecting circulating fibrinogen levels in the Framingham Heart Study. Thromb Res 2003, 110:57-64

107. Sunyer J, Pistelli R, Plana E, Andreani M, Baldari F, Kolz M, Koenig W, Pekkanen J, Peters A, Forastiere F: Systemic inflammation, genetic susceptibility and lung function. Eur Respir J 2008, 32:92-97.

108. Bazzano LA, He J, Muntner P, Vupputuri S, Whelton PK: Relationship between cigarette smoking and novel risk factors for cardiovascular disease in the United States. Ann Intern Med 2003, 138:891-897.

109. Wannamethee SG, Lowe GD, Shaper AG, Rumley A, Lennon L, Whincup PH: Associations between cigarette smoking, pipe/cigar smoking, and smoking cessation, and haemostatic and inflammatory markers for cardiovascular disease. Eur Heart J 2005, 26:1765-1773.

110. Lind P, Hedblad B, Hultberg B, Stavenow L, Janzon L, Lindgarde F: Risk of myocardial infarction in relation to plasma levels of homocysteine and inflammation-sensitive proteins: a long-term nested case-control study. Angiology 2003, 54:401-410.

111. Kaptoge S, White IR, Thompson SG, Wood AM, Lewington S, Lowe GD, Danesh J: Associations of plasma fibrinogen levels with established cardiovascular disease risk factors, inflammatory markers, and other characteristics: individual participant meta-analysis of 154,211 adults in 31 prospective studies: the fibrinogen studies collaboration. Am J Epidemiol 2007, 166:867-879.

112. Engstrom G, Segelstorm N, Ekberg-Aronsson M, Nilsson PM, Lindgarde F, Lofdahl CG: Plasma markers of inflammation and incidence of hospitalisations for COPD: results from a population-based cohort study. Thorax 2009, 64:211-215.

113. Dahl M, Tybjaerg-Hansen A, Vestbo J, Lange P, Nordestgaard BG: Elevated plasma fibrinogen associated with reduced pulmonary function and increased risk of chronic obstructive pulmonary disease. Am J Respir Crit Care Med 2001, 164:1008-1011.

114. Mannino DM, Valvi D, Mullerova $H$, Tal Singer R: Fibrinogen, COPD and mortality in a nationally representative U.S. cohort. COPD 2012, 9:359-366.

115. Jiang R, Burke GL, Enright PL, Newman AB, Margolis HG, Cushman M, Tracy RP, Wang Y, Kronmal RA, Barr RG: Inflammatory markers and longitudinal lung function decline in the elderly. Am J Epidemio/ 2008, 168:602-610.

116. Duvoix A, Dickens J, Haq I, Mannino D, Miller B, Tal Singer R, Lomas DA: Blood fibrinogen as a biomarker of chronic obstructive pulmonary disease. Thorax 2012, 68:670-676.

117. Cockayne DA, Cheng DT, Waschki B, Sridhar S, Ravindran P, Hilton H, Kourteva G, Bitter H, Pillai SG, Visvanathan S, Müller KC, Holz O, Magnussen $\mathrm{H}$, Watz H, Fine JS: Systemic biomarkers of neutrophilic inflammation, tissue injury and repair in COPD patients with differing levels of disease severity. PLoS One 2012, 7:e38629.

118. Donaldson GC, Seemungal TA, Patel IS, Bhowmik A, Wilkinson TM, Hurst JR, MacCallum PK, Wedzicha JA: Airway and systemic inflammation and decline in lung function in patients with COPD. 2005. Chest 2009, 136:e30.

119. Higashimoto Y, Iwata T, Okada M, Satoh H, Fukuda K, Tohda Y: Serum biomarkers as predictors of lung function decline in chronic obstructive pulmonary disease. Respir Med 2009, 103:1231-1238.

120. Papaioannou Al, Mazioti A, Kiropoulos T, Tsilioni I, Koutsokera A, Tanou K, Nikoulis DJ, Georgoulias P, Zakynthinos E, Gourgoulianis Kl, Kostikas K: Systemic and airway inflammation and the presence of emphysema in patients with COPD. Respir Med 2010, 104:275-282.

121. Wedzicha JA, Seemungal TA, MacCallum PK, Paul EA, Donaldson GC, Bhowmik A, Jeffries DJ, Meade TW: Acute exacerbations of chronic obstructive pulmonary disease are accompanied by elevations of plasma fibrinogen and serum IL-6 levels. Thromb Haemost 2000, 84:210-215.

122. Thomsen $M$, Ingebrigtsen TS, Marott $J$, Dahl M, Lange $P$, Vestbo J, Nordestgaard BG: Inflammatory biomarkers and exacerbations in chronic obstructive pulmonary disease. JAMA 2013, 309:2353-2361.

123. Seemungal T, Harper-Owen R, Bhowmik A, Moric I, Sanderson G, Message $S$, Maccallum P, Meade TW, Jeffries DJ, Johnston SL, Wedzicha JA: Respiratory viruses, symptoms, and inflammatory markers in acute exacerbations and stable chronic obstructive pulmonary disease. Am J Respir Crit Care Med 2001, 164:1618-1623.
124. Meade TW, Ruddock V, Stirling Y, Chakrabarti R, Miller GJ: Fibrinolytic activity, clotting factors, and long-term incidence of ischaemic heart disease in the Northwick Park Heart Study. Lancet 1993, 342:1076-1079.

125. Emerging Risk Factors Collaboration, Kaptoge S, Di Angelantonio E, Pennells L, Wood AM, White IR, Gao P, Walker M, Thompson A, Sarwar N, Caslake M, Butterworth AS, Amouyel P, Assmann G, Bakker SJ, Barr EL, Barrett-Connor E, Benjamin EJ, Björkelund C, Brenner H, Brunner E, Clarke R, Cooper JA, Cremer P, Cushman M, Dagenais GR, D'Agostino RB Sr, Dankner R, DaveySmith G, Deeg D, et al: C-reactive protein, fibrinogen, and cardiovascular disease prediction. N Engl J Med 2012, 367:1310-1320.

126. Valvi D, Mannino DM, Mullerova H, Tal-Singer R: Fibrinogen, chronic obstructive pulmonary disease (COPD) and outcomes in two United States cohorts. Int J Chron Obstruct Pulmon Dis 2012, 7:173-182.

127. Kunter E, Ilvan A, Ozmen N, Demirer E, Ozturk A, Avsar K, Sayan O, Kartaloglu Z: Effect of corticosteroids on hemostasis and pulmonary arterial pressure during chronic obstructive pulmonary disease exacerbation. Respiration 2008, 75:145-154.

128. Casaburi R, Celli B, Crapo J, Criner G, Croxton T, Gaw A, Jones P, Kline-Leidy N, Lomas DA, Merrill D, Polkey M, Rennard S, Sciurba F, Tal-Singer R, Stockley R, Turino G, Vestbo J, Walsh J: The COPD Biomarker Qualification Consortium (CBQC). COPD 2013, 10:367-377.

\section{doi:10.1186/s12931-014-0147-5}

Cite this article as: Lock-Johansson et al:: Surfactant protein D, Club cell protein 16 , Pulmonary and activation-regulated chemokine, C-reactive protein, and Fibrinogen biomarker variation in chronic obstructive lung disease. Respiratory Research 2014 15:147.

\section{Submit your next manuscript to BioMed Central and take full advantage of:}

- Convenient online submission

- Thorough peer review

- No space constraints or color figure charges

- Immediate publication on acceptance

- Inclusion in PubMed, CAS, Scopus and Google Scholar

- Research which is freely available for redistribution 